\title{
Endangered Gladiolus Species of Turkey
}

\author{
Sevim Demir ${ }^{1, a, *}$, Fisun Gürsel Çelikel ${ }^{1, b}$ \\ Department of Horticulture, Agricultural Faculty, Ondokuz Mayis University, 55105 Atakum/Samsun, Turkey \\ *Corresponding author
}

\section{A R T I C LE I N F O}

Review Article

Received : 12/09/2017

Accepted : 07/05/2019

Keywords: Gladiolus italicus

IUCN

Red List

Geophyte

Genetic Diversity

\section{A B S T R A C T}

Gladiolus is a perennial geophyte, semi-rustice herb and belongs to the Iridaceae family. Gladiolus is an important bulbous ornamental plant. It is used as cut flowers, garden and potted plants. Turkey, which is among the major gene centers of the world and has a special place in plant genetic diversity, has rich genetic resources of geophytes including Gladiolus. However, many plant genetic resources, including Gladiolus are under genetic erosion because of the environmental and other problems and therefore face with the danger of extinction. Turkey has one Gladiolus species in IUCN Red List category. This species is Gladiolus italicus and its Red list category is Least Concern (LC). Gladiolus italicus is distributed in Macaronesia, Mediterranean basin to central Asia. Also introduced and naturalized in California. It naturally grows in many parts of Turkey. The other Gladiolus species that are reported to be under threat in Turkey are; Gladiolus anatolicus, Gladiolus antakiensis, Gladiolus halophilus, Gladiolus humilis, Gladiolus micranthus. In addition to their potential usage as ornamental plants, their usage in phytomedicine due to the medical properties of the modified stems, leaves and in other related industries increases their importance. Therefore, it is very important to protect these genetic resources of Gladiolus.

Türk Tarım - Gıda Bilim ve Teknoloji Dergisi 7(5): 693-697, 2019

\section{Türkiye'nin Nesli Tehlike Altında Olan Gladiolus Türleri}

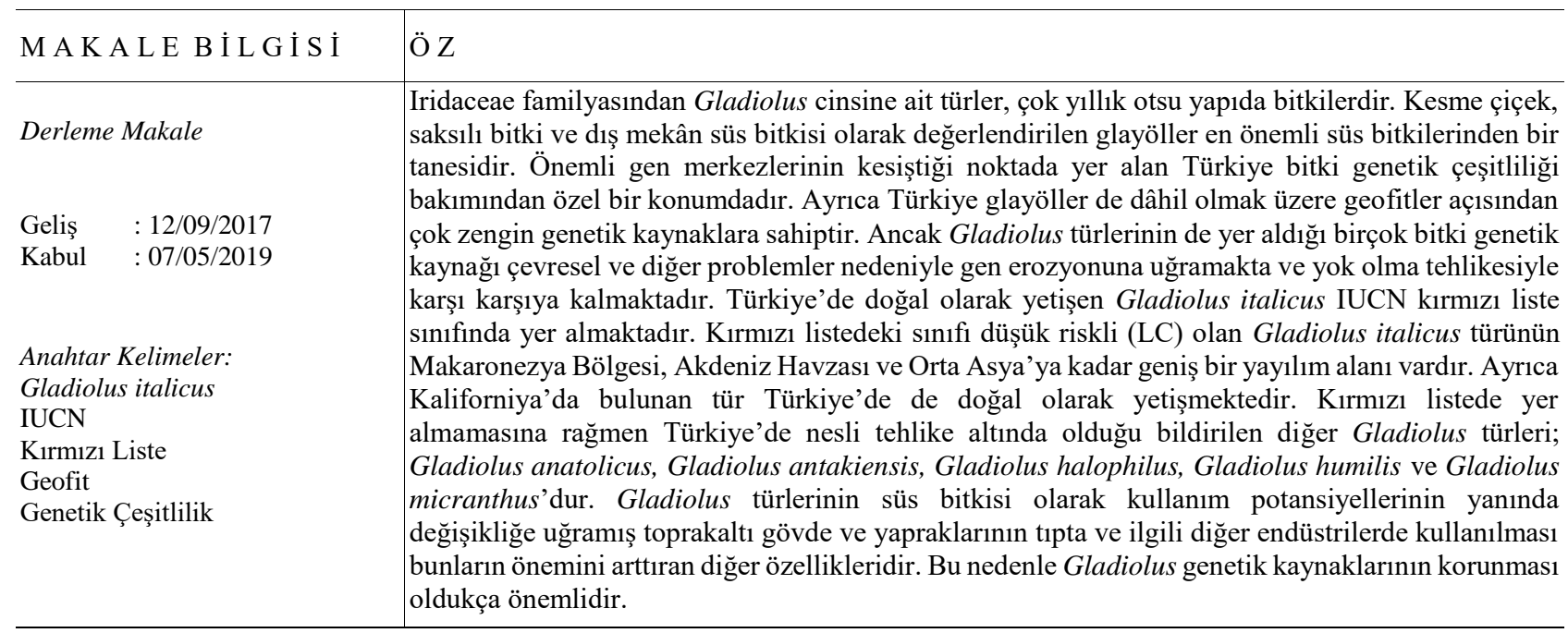




\section{Introduction}

Gladiolus is a perennial geophyte, semi-rustice herb, and belongs to the Iridaceae family. The genus Gladiolus is widely distributed throughout the world (Lewis et al., 1972; Gonzalez et al., 2003). The current number of species in the genus Gladiolus appears to be more than 255 centered in the Sothern Africa extended throughout tropical Africa and Madagascar and into the Arabian Peninsula, the Mediterranean basin, Europe and Asia as far as Iran, Afghanistan (Cantor and Tolety, 2011). Today Gladiolus is one of the world's most important bulbous ornamental garden plant and as a cut flower crop used for bouquets and arrangements (Cantor and Tolety, 2011).

Turkey, which is among the major gene centers of the world and has a special place in plant genetic diversity, has rich genetic resources of geophytes including Gladiolus. A total 12.476 taxa including 4.080 endemic species live on 78 million hectares spread over Europe and Asia. The richness of our plant genetic diversity is due to the topography of our country, its geological structure and its different soil structure depending on different climatic conditions (Karagöz et al., 2010; Çelikel, 2014).

The native flower bulbs are used in pharmacology and in other related industries other than ornamental sector. However most of the geophytes were endangered because of over collecting for export, industrialization, road and building construction, tourism activities, overgrazing, stone quarry and similar reasons. Ministry of Food, Agriculture and Livestock issued a regulation on collection, production and marketing of natural flower bulbs in 1989 to protect the flora of Turkey (Çelikel, 2014; 2015).

Turkey has one Gladiolus species in IUCN Red List category. This species is Gladiolus italicus and its Red list category is Least concern (LC) (Contu, 2013). Gladiolus italicus is distributed in Macaronesia, Mediterranean basin to central Asia. Also introduced and naturalized in California. It naturally grows in many parts of Turkey (Contu, 2013). The other Gladiolus species that are reported to be under threat in Turkey are; Gladiolus anatolicus, Gladiolus antakiensis, Gladiolus halophilus, Gladiolus humilis, Gladiolus micranthus. In addition to their potential usage as ornamental plants, their usage in phytomedicine due to the medical properties of the modified stems, leaves and in other related industries increases their importance. Attard and Pacioni (2011) reported that according to Penza (1969) and Borg (1927) leaves and bulb of Gladiolus italicus use as galactogogue, aphrodisiac and emmenagogue. Therefore, it is very important to protect these genetic resources of Gladiolus and prevent their destruction. This review has been prepared to take attentions on the importance and conservation of endangered Gladiolus species grown in Turkey.

\section{International Union for Conservation of Nature and Natural Resources, IUCN}

The IUCN Red List Categories and Criteria, is designed as an easily understood system for classifying species at high risk of global extinction. The purpose of the system is to classify different species according to their extinction risk, take the attention to species that have high of risk of extinction, identify the priorities among conservation studies. The Red List status of taxa is one of the most widely used indicators for assessing the condition of ecosystems and their biodiversity. It also provides an important tool in establishing priorities for species conservation (IUCN, 2012). The IUCN Red List Categories and Criteria are designed to determine a taxon's relative risk of extinction, with the main purpose of cataloguing and highlighting those taxa that are facing a higher risk of extinction. The IUCN Red List provides taxonomic, distribution, ecological, threat and conservation status information on taxa that have been evaluated using the IUCN Red List Categories and Criteria (IUCN, 2012; Allen et al., 2014). The IUCN Red List Categories (Fig. 1) are based on a set of quantitative criteria linked to population trends, population size and structure, and geographic range. There are nine categories, ranging from Not Evaluated (NE), where a species has not been evaluated against the Red List Criteria, Least Concern (LC), for species that are not threatened, and to Extinct (EX), for species that have disappeared from the planet. Species classified as Vulnerable (VU), Endangered (EN) and Critically Endangered (CR) are classed as 'Threatened'. 'Near Threatened' (NT) species are considered to be close to meeting the threshold for a threatened category, and they may be considered 'conservation dependent', reliant on specific conservation actions to maintain (Allen et al., 2014).

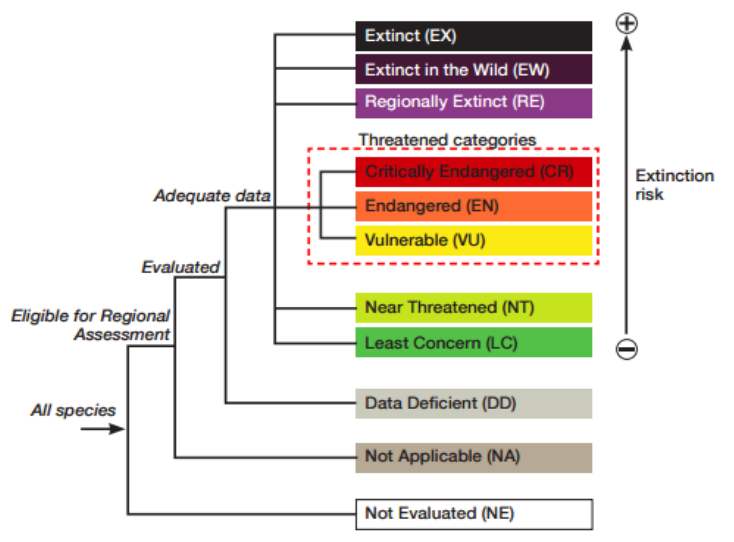

Fig. 1 IUCN Red List Categories (Allen et al, 2014)

\section{Gladiolus Species of Turkey in IUCN Red List Categories}

There is only one Gladiolus species (Gladiolus italicus) in our country in Least Concern (LC) category of IUCN Red List.

\section{Gladiolus italicus}

This species is generally common in its natural range and it has been introduced in some countries where it is now naturalized. It shows a general weedy behavior in the areas in which is distributed.

Red list category: Threat category is Least Concern (LC) for Gladiolus italicus.

Habitat and ecology: This species is a tuber geophyte which grows in Mediterranean woodlands, shrublands, grasslands and in disturbed habitats (roadsides and cultivated fields). 


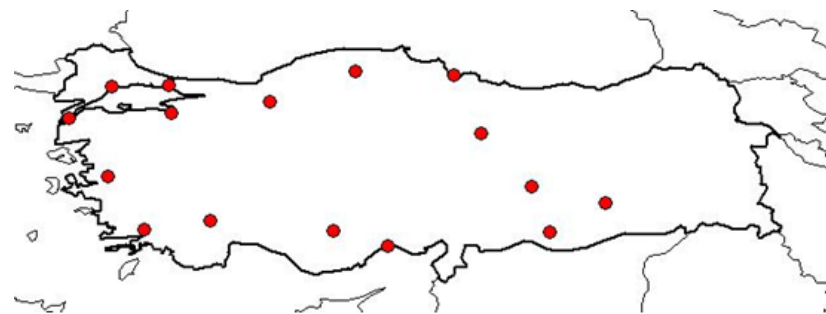

(A)

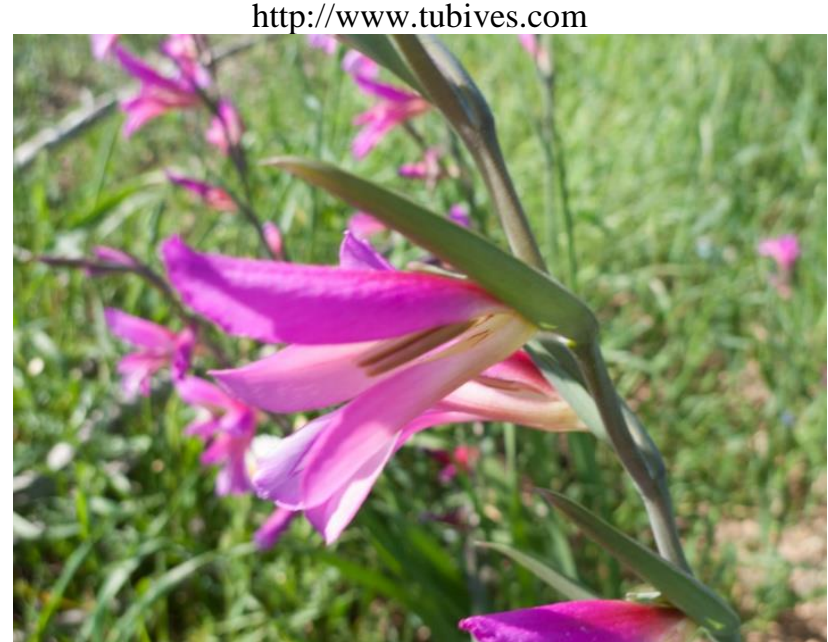

(B)

Fig. 2 Distribution areas (A) and flowers (B) of Gladiolus

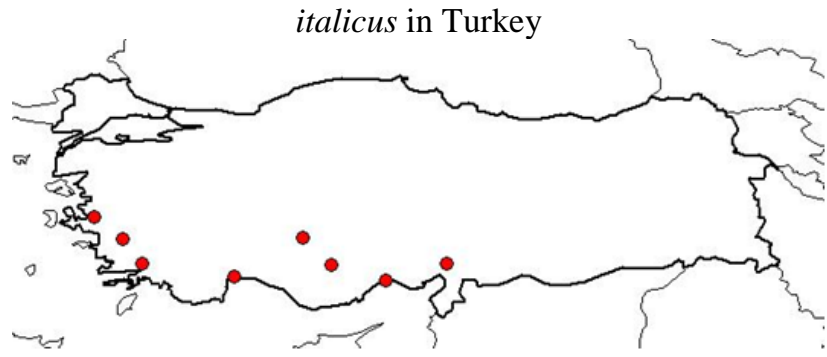

(A)

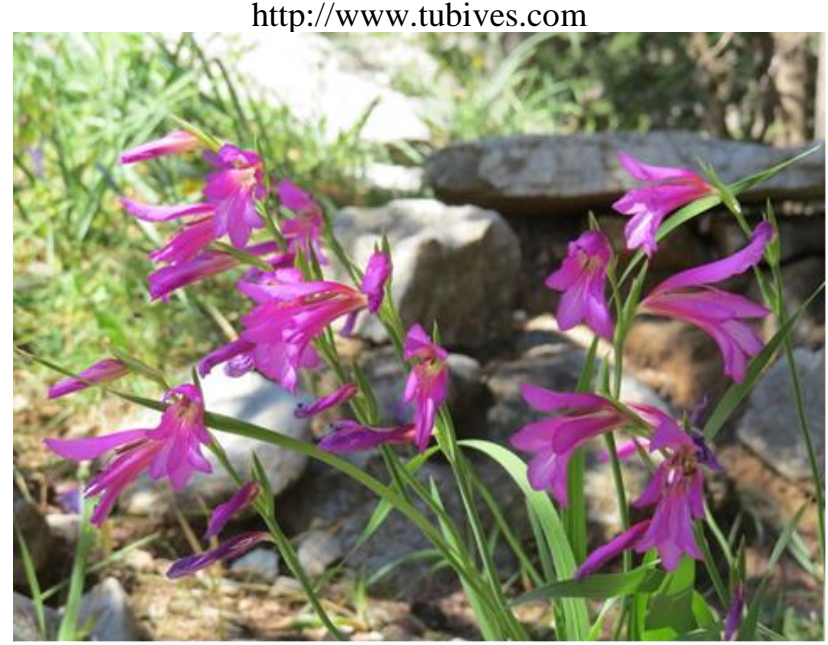

(B)

Fig. 3 Distribution areas (A) and flowers (B) of Gladiolus anatolicus in Turkey

Range description and countries occurrence: Gladiolus italicus is distributed in Macaronesia, Mediterranean basin to central Asia. Also introduced and naturalized in California. Native distribution areas are, Albania, Cyprus, Egypt, France, Greece, Iran, Islamic Republic of Iraq, Italy, Kuwait, Lebanon, Macedonia, the former Yugoslav Republic of Malta, Morocco, Oman, Portugal, Saudi Arabia, Spain, Syrian Arab Republic, Tunisia and Turkey (Contu, 2013). Distribution areas of Gladiolus italicus in Turkey are Bolu, Istanbul, Kastamonu, Burdur, Bursa, Çanakkale, Diyarbakir, Içel, Malatya, Manisa, Muğla, Samsun, Sivas, Tekirdağ, Şanliurfa, Karaman (Tubives, 2018). Distribution areas (A) and flowers (B) of Gladiolus italicus in Turkey are given in Fig. 2.

Use and trade: This species is used as ornamental plant (Contu, 2013). Leaves and bulb of Gladiolus italicus use as galactogogue, aphrodisiac and emmenagogue (Attard and Pacioni, 2011).

Endemism: It is not endemic (Contu, 2013).

Major threats: There are no known major threats for the species.

Other Gladiolus species that are under threat in Turkey

There are 5 Gladiolus species that are reported to be under threat in Nezahat Gökyiğit Botanical garden (Tehditaltındakibitkiler, 2017) as follows:

- Gladiolus anatolicus: It is endemic to Turkey. This species is distributed in Osmaniye, Antalya, Aydın, Içel, Izmir, Konya, Muğla, Karaman the cities of Turkey. Distribution areas (A) and flowers (B) of Gladiolus anatolicus are shown in Fig. 3.

- Gladiolus antakiensis: Native distribution areas of Gladiolus antakiensis in Turkey are Siirt, Şırnak, Hatay. Distribution areas (A) and flowers (B) of Gladiolus antakiensis are given in Fig. 4.

- Gladiolus halophilus: It is endemic to Turkey. This species is distributed in Erzincan, Konya, Niğde the cities of Turkey. Distribution areas (A) and flowers (B) of Gladiolus halophilus are shown in Fig. 5.

- Gladiolus humilis: It is endemic to Turkey. Native distribution area of Gladiolus humilis in Turkey is Adiyaman. Distribution area of Gladiolus humilis is given in Fig. 6.

- Gladiolus micranthus: It is endemic to Turkey. Native distribution area of Gladiolus micranthus in Turkey are Burdur and Muğla Distribution areas (A) and flowers (B) of Gladiolus micranthus are given in Fig. 7.

\section{Conservation Actions}

Ministry of Food, Agriculture and Livestock issued a regulation on collection, production and marketing of natural flower bulbs in 1989 to protect the flora of Turkey (Çelikel, 2014). This regulation was published in the Turkish Governmental Journal (Resmi Gazete no. 20059, 24-01-1989) on the production and the export of bulbs, tubers and roots of flowers (Kasparek and Grimm, 1999). According to the regulation, some species of trade are completely prohibited, while some species have quotas for trade. Every year until the end of October, the official gazette publishes the genus, species and amount of flower bulbs to be exported, the genus and species of the flower bulbs which are forbidden to export under the name 'Export List of Natural Flower Bulbs' by the Ministry. This regulation prohibits the international trade of all Gladiolus species (Resmigazete, 2017). 


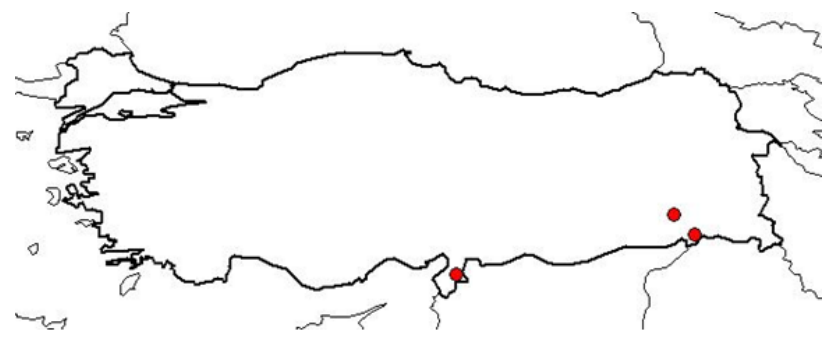

(A)

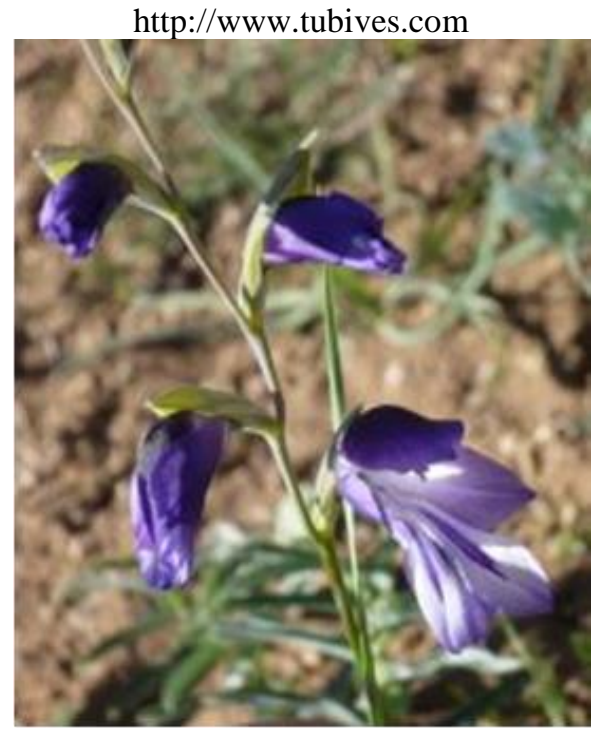

(B)

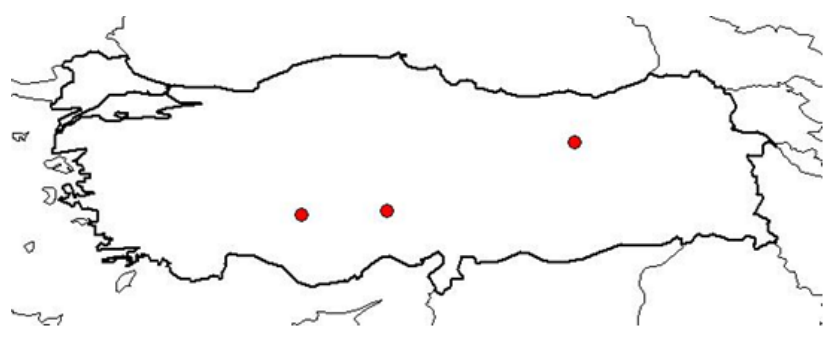

(A)

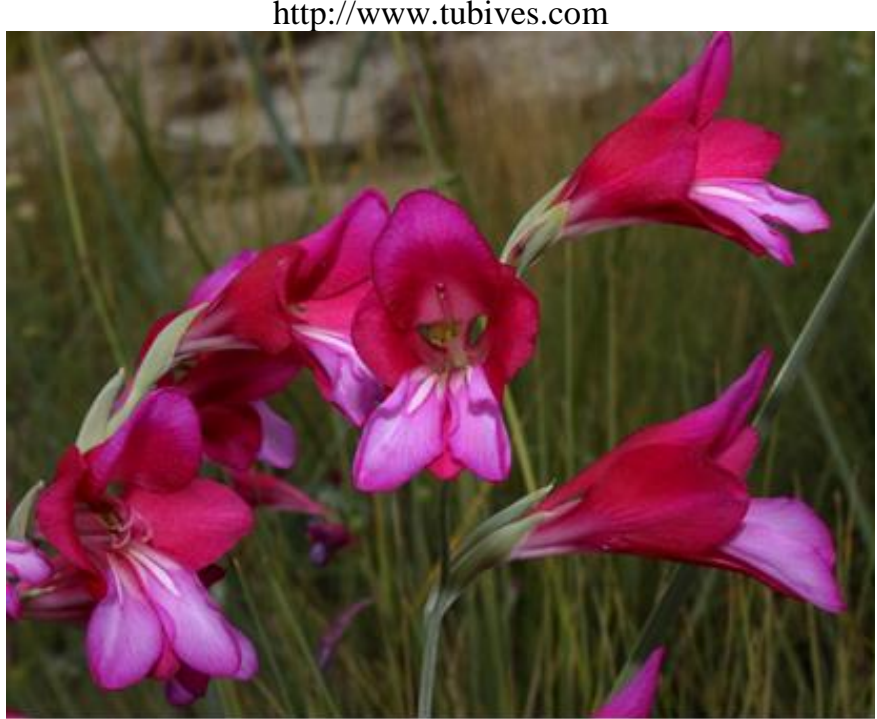

(B)

Fig. 4 Distribution areas (A) and flowers (B) of Gladiolus Fig. 5 Distribution areas (A) and flowers (B) of Gladiolus antakiensis in Turkey halophilus in Turkey

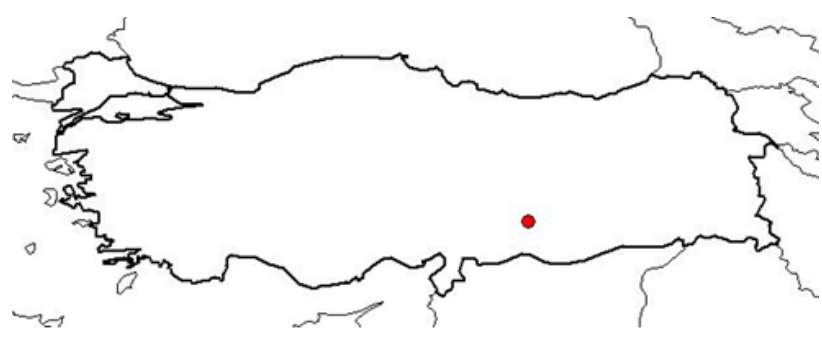

(A)

http://www.tubives.com

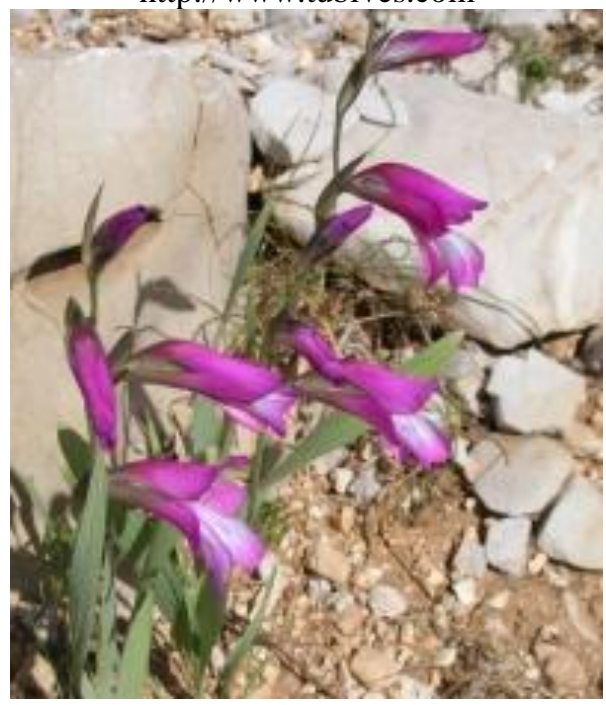

Fig. 6 Distribution areas (A) and flowers (B) of Gladiolus humilis in Turkey

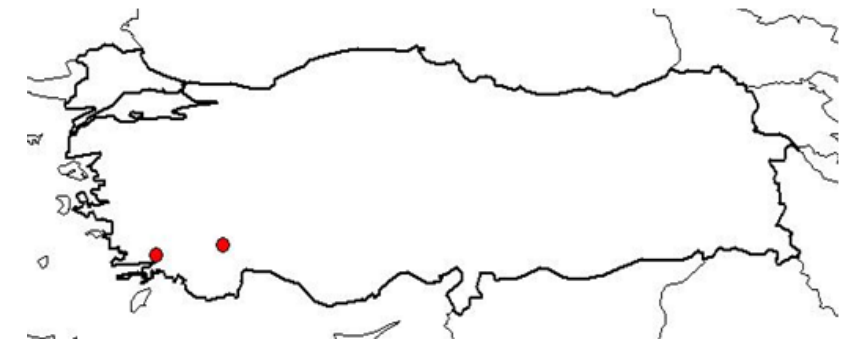

(A)

http://www.tubives.com

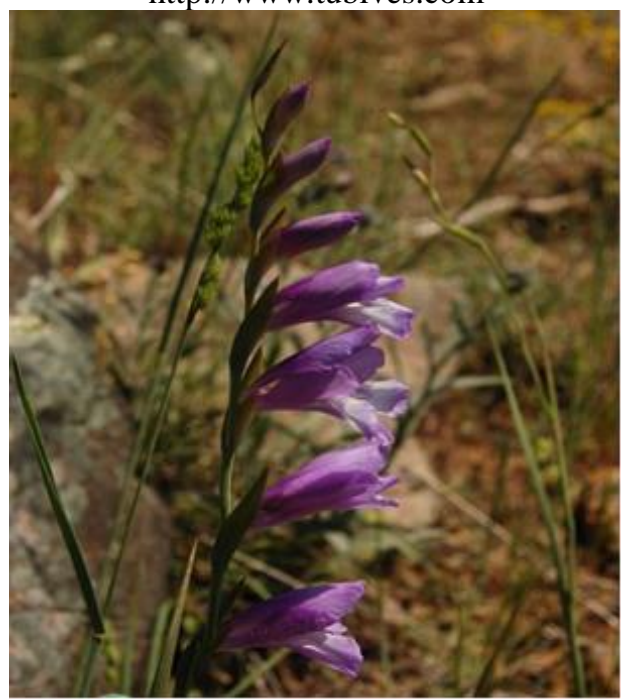

Fig. 7 Distribution areas (A) and flowers (B) of Gladiolus micranthus in Turkey 
Turkey has signed the CITES (The Convention on International Trade in Endangered Species of Wild Fauna and Flora) Convention in 1996. CITES is an international agreement in order to prevent threats against wild animals and plants species because of international trade. Convention lists the species afforded different levels or types of protection from over-exploitation. But Gladiolus species are not included in CITES (CITES, 2017). Probably since these species have not been traded, they were not included in CITES.

There are no other known conservation measures specifically for Gladiolus italicus, but it is known to occur in some protected areas according to Contu (2013).

\section{Conclusion and Suggestions}

In order to save the threatened species of Gladiolus in flora of Turkey, some measures should be taken. Prohibit or control the collection of all native plants by plant lovers as well as by collectors without a special permit is of important. Export should be mostly allowed from production instead of flora. The government must increase the legislative measures on this matter. However, these conservation measures aren't sufficient to completely reduce the risk of extinction, notably due to problems in applying the law as well as inadequate management of the protected areas. Therefore, educating the local people about the importance of the native plants under threat and thus increasing the realization is of importance for gaining their attention and care to flora (Çelikel, 2014; Çelikel, 2015; Demir and Çelikel, 2017a; Demir and Çelikel, 2017b).

The endangered Gladiolus species must be conserved in botanical gardens or seed banks which are known as ex situ conservation or cultivation. Cultivation and propagation studies on these species should be encouraged and increased. An experiment was conducted to study propagation of Gladiolus by corm and this study showed that using half corm may be beneficial for farmers by reducing half of the planting materials (Mahasen et al., 2015). It was reported that spraying TIBA (triiodobenzoic acid) at $500 \mathrm{ppm}$ and dipping into kinetin at $500 \mathrm{ppm}$ increased the number of corms and cormels in Gladiolus cultivars (Baskaran et al., 2009). It was understood that propagation of Gladiolus species can achieve by corm (Baskaran et al., 2009; Mahasen et al., 2015). But it is known that if the species disappears in the wild, it will be difficult to reintroduce the species to the flora. Therefore the species should be maintained in their natural habitat which is known as in situ conservation. Creation and management of protected areas are important for native plants (Montmollin and Strahm, 2005; Demir and Çelikel, 2017a; Demir and Çelikel, 2017b).

The main conservation measures for Gladiolus species and their habitat are to continue investigating their biology and ecology as well as propagation methods and cultivating techniques. In addition, management of grazing, control of invasive species, cultivation in botanical gardens or maintenance in seed banks, reintroduction or reinforcement of populations are among the main measures in order to save endangered Gladiolus species and other native plants of Turkey.

\section{References}

Allen D, Bilz M. Leaman DJ, Miller RM, Timoshyna A, Window J. 2014. European Red List of Medicinal Plants. Luxembourg: Publications Office of the European Union.

Attard E, Pacioni P. 2011. The Phytochemical and In Vitro Pharmacological Testing of Maltese Medicinal Plants. Edited by Rasooli I. Bioactive Compounds In Phytomedicine., Croatia, 93-112. ISBN 978-953-307-805-2

Baskaran V, Misra RL, Abirami K. 2009. Effect of plant growth regulators on corm production in gladiolus. J. Hortl. Sci. 4 (1): 78-80.

Borg J. 1927. Descriptive Flora of the Maltese Islands, Government Printing Office, Malta.

Cantor M, Tolety J. 2011. Gladiolus, Edited by Kole C., Wild Crop Relatives: Genomic and Breeding Resources, Plantation and Ornamental Crops. Springer, Berlin, Heidelberg. ISBN 978-3-642-21201-7

CITES, https://cites.org/eng/app/index.php, (Accessed on: 28 Apr 2017).

Contu S. 2013. Gladiolus italicus. The IUCN Red List of Threatened Species 2013: e.T18990775A44502078. http://dx.doi.org/10.2305/IUCN.UK.2013

2.RLTS.T18990775A44502078.en. Downloaded on 24 July 2017.

Çelikel FG. 2014. Geophytes and Ornamental Plants, Lecture Notes (in Turkish). Ondokuz Mayis University, Faculty of Agriculture, Department of Horticulture, Samsun.

Çelikel FG. 2015. Süs bitkilerinde tohumluk (tohum, fide, fidan, soğan) üretimi ve kullanımı. SÜSBİR. (3): 32-33.

Demir S, Çelikel FG. 2017a. Different properties and importance of Pancratium maritimum naturally grown in Turkey. Turkish Journal of Agriculture - Food Science and Technology, 5(13): 1726-1731. DOI: https://doi.org/10.24925/turjaf.v5i13.17261731.1507

Demir S, Çelikel FG. 2017b. Endangered Lilium species of Turkey. Turkish Journal of Agriculture - Food Science and Technology, 5(13): $1796-1801 . \quad$ DOI: https://doi.org/10.24925/turjaf.v5i13.1796-1801.1506

Gonzalez A, Lopez J, Banon S, Ochoa J, Fernandez JA, Martinez JJ, Rodriguez R. 2003. Ornamental use of wild species of genus Gladiolus. Proc. IS on Sust. Use of Plant Biodiv. E. Düzyaman \&Y.Tüzel Acta Hort. 598, ISHS 2003.

IUCN 2012. IUCN Red List Categories and Criteria: Version 3.1. Second edition. Gland, Switzerland and Cambridge, UK: IUCN. iv + 32pp.

Karagöz A, Zencirci N, TAN A, Taşkın T, Köksel H, Sürek M, Toker C, Özbek K. 2010. Bitki genetik kaynaklarının korunması ve kullanımı, Türkiye Ziraat Mühendisliği VII. Teknik Kongresi, 11-15 Jan, p. 155-177. Ankara, Turkey.

Kasparek M, Grimm U. 1999. European trade in Turkish Salep with special reference to Germany. Economic Botany, 53(4): 396-406.

Lewis GJ, Obermeyer AA, Barnard TT. 1972. A revision of the South African species of Gladiolus. J. S. Afican Bot., Suppl., 10: $1-316$.

Mahasena M, Ona AF, Taufique T, Mehraj H, Jamal Uddin AFM. 2015. Suitability of cut corm as planting materials on flowering and corm-cormel production of gladiolus cultivars. J. Biosci. Agric. Res. 04(01): 10-19.

Montmollin B, de Strahm W. (Eds). 2005. The top 50 Mediterranean Island Plants: Wild plants at the brink of extinction, and what is needed to save them. IUCN/SSC Mediterranean Islands Plant Specialist Group. IUCN, Gland, Switzerland and Cambridge, UK. $\mathrm{x}+110 \mathrm{pp}$.

Penza C. 1969. Flora Maltija Medicinali, Progress Press Co. Ltd., Malta.

Resmigazete 2017. Export table of natural flower bulbs, www.resmigazete.gov.tr, (Accessed on 28.05.2017).

Tehditaltındakibitkiler 2017. www.tehditaltindabitkiler.org.tr (Accessed on 24.07.2017).

Tubives 2018. www.tubives.com. (Accessed on 24.07.2017). 